\title{
ANAMNESTIC, CLINICAL AND PATHOMORPHOLOGICAL CHARACTERISTICS OF MALIGNANT MAMMARY TUMORS AND DYSPLASIA IN DOGS
}

\author{
N. I. MYKHALENKO, PhD, Associate professor of \\ Department of Animal Anatomy, Histology and Pathomorphology \\ named after Academician V. G.Kasianenko \\ https://orcid.org/0000-0001-6841-374X \\ E. O. KMITEVYCH, doctor of veterinary medicine, \\ https://orcid.org/0000-0002-6646-5535 \\ National University of Life and Environmental Sciences of Ukraine \\ E-mail:nmemail@ukr.net
}

\begin{abstract}
Parameters of 37 canine mammary malignant tumors and 13 dysplasia were compared. The age of an animal at the time of treatment in veterinary clinic, the age of the first factors of neoplasm, the number of births during life and the period of the last one, feeding nature, pseudo pregnancy and lactation cases, the number and location of affected mammary gland, neoplasm macro characteristics were considered. The size of the letter was determined with a view to three factors, the occurrence of capsules in neoplasms was ranked in points. The intensity of lactation malfunction was determined under the same method.

Canine mammary dysplasia was examined at an earlier age than malignant tumors. This is partly due to the earlier onset than in the case of malignant tumors. At the same time, period between cancer discovery and treatment in the latter case was much shorter. It may state faster growth of tumors in case of malignancy than in mammary dysplasia. A significant difference in neoplasms size - malignant tumor and dysplasia is the proof thereof.Study of the influence of the number of births in the occurrence of different mammary neoplasms showed that dogs with dysplasia gave birth twice as less than those with diagnosed malignant tumors. The period between the last birth and identification of factors of disease for both groups of animals was the same. There was no significant difference also in the frequency of cases with lactation malfunction in dogs with mammary malignant tumors and dysplasia. Groups of animals with mammary malignant tumors and dysplasia differed on such characteristics as frequency of tumors with full, partial or no capsule, and the average number of mammary gland affected and their localization.
\end{abstract}

Keywords: veterinary oncology, mammary tumors, malignant tumors, mammary dysplasia, dogs 


\section{Introduction}

The largest share in the total structure of cancer pathology in dogs is mammary gland tumors. Underintegrated data theymake up to $48 \%$ of all tumors in animals (Kosmacheva, 2003; Junters et al., 2000) and $80 \%$ of tumors in reproductive females (Alessandro et al., 2014). With malignant mammary neoplasia ranking first - up to $70 \%$ of all malignant tumors in dogs (Kosmacheva, 2003; Salas et al., 2015).

The risk ofmammarytumors in dogs, including cancer, is generally similar to those in humans (Martin de las Mulas and Reymundo, 2000). In women, the presence of atypical mammarycell hyperplasia is the second (after genetic factor) of risk factorsthat increases the incidence of mammarycancer compared with the population level (Fitzgibbons et al., 1998). In canine dysplasia is often determined in tissue surrounding the mammary tumor (Meuten, 2002). However, despite this, the study of the role of such abnormality in future malignancy is extremely insufficient and some authors believe that the role of this factor is either unknown or negligible (Martin de las Mulas\&Reymundo, 2000).

Even in early works the inverse relationship between the number of births and the occurrence ofmammary tumors in dogs was identified (Kosmacheva, 2003). The work on this issue are rare, however, researchers still tend to believe that malignant mammarytumors in dogs occure more often in animals that gave no birth or gave birth once or twice (Chehun\&Mazurkevich, 2001). It is believed that failure to give birth during 5-6 years can also affect the incidence of malignant tumors (Meuten, 2002). In addition, the case of mammarytumors in female dogs can lead to dysfunctional states of the reproductive system, most clearly in relation to benign tumors (Kosmacheva, 2003; Nguyen et al., 2018). The postdiestral lactation syndrome should be considered (Veronesi et al., 2003). At the same time, other researchers say that postdiestral syndrome is not a risk factor for mammary tumors (Trapezov, 2004), and lactation during pseudopregnancy in this process is under question (Meuten, 2002). Animals that have given birth during their life, but whose puppies were killed immediately after birth, are under risk of mammarytumor. It is due to deep non-physiologicalmammary dysfunction (Nguyen et al., 2018). It should at least be noted that most of these conclusions are made without full-fledged research with identificationof specific hormonal factors and mechanisms, and are a priori based on data and conclusions obtained for humans.

The research is aimed at the comparative analysis of some anamnesis, clinical and pathological characteristics of canine mammary cancer and dysplasia.

\section{Materials and Methods}

50 cases of mammary tumors in dogs were studied. The material was fixed in $10 \%$ neutral formalin solution. The fixed pieces were placed in a mixture of ethanol $96^{\circ}$ and formalin (1:1). After, the material was tripled through ethanol $96^{\circ}$. The material was sealed by immersion in paraffin. Before compaction, the material was carried out using mixtures of ethanol $96^{\circ}$ and xylene $(1: 1)$ and three times xylene. Ethanol $96^{\circ}$ Ukrspirt (Ukraine), xylene and paraffin from Fisher (USA) were used.Filling the material in paraffin blocks was performed on a machine for filling "LAMB". The sections were prepared on a rotational microtome of the company "Leica", the thickness of the sections is 2 microns. Object glasses 
of the "Matsunami" (Japan) were used. The finished sections were placed in a thermostat, after which they were stained according to generally accepted schemes of hematoxylinum of Karachi and eosin (Goral's'kyj, 2015). After staining, dehydration was performed with ethanol $96^{\circ}$, carried out through xylene and enclosed in a balsam. Reagents were prepared according to generally accepted prescriptions (Lilli, 1969). For staining, ethanol $96^{0} \mathrm{Ukrspirt}$ (Ukraine), xylene, paint and the balm of the "Fisher" (USA), cover coats of the "Matsunami" (Japan) were used.Histologic types were determined by the International Histology Classification of WHO (Misdorp, 1999).

Afterpathomorphological studies 37 mammary malignant tumors and 13 cases of fibrocystic disease (dysplasia) were diagnosed. The age of an animal at the time of treatment in veterinary clinic, the age of the first factors of neoplasm, the number of births during life and the period of the last one, feeding nature, pseudopregnancy and lactation cases, the number and location of affected mammary gland, neoplasm macrocharacteristics were considered. The size of the letter was determined with a view to three factors, the occurrence of capsules in neoplasms was ranked in points (no -0 , partial -1 , full 2 ). The intensity of lactation malfunctionwas determined under the same method (no pseudopregnancy and lactation - 0, pseudopregnancy without lactation -1 , pseudopregnancy with lactation -2 , artificial inhibition of lactation after giving birth - 1). The data were processed statistically with a view to t-Student criterion.

\section{Results}

Due to the Table belowmammarydysplasia in dogs was examined at an earlier age than malignant tumors. This is partly due to the earlier onset (average 7 years) than in the case of malignant tumors ( 9 years). At the same time, period between cancer discovery and treatment in the latter case was much shorter. It may state faster growth of tumors in case of malignancy than in mammaryfibrocystic disease. A significant difference in neoplasms size - malignant tumor and dysplasia is the proof thereof.

Pregnancy promotes maturation (differentiation) of mammary epithelium, considering an important preventive fact against the hormone-dependent tumors. Thus, decrease of estrogen receptor and epidermal growth factor in mammary gland inrats that gave birth, compared with those who had no pregnancy and childbirth resultin a lower risk of tumors (Blank et al., 2008).Study of the influence of the number of births in the occurrence of different mammary neoplasmsshowed that dogs with dysplasia gave birth twice as less than those with diagnosed malignant tumors (Table 1). The period between the last birth and identification of factors of disease for both groups of animals was the same - about 5 years. There was no significant difference also in the frequency of cases with lactation malfunction in dogs with malignant tumors and in dogs withmammaryfibrocystic diseases. At the same time, attention is drawn to the fact that in dogs with mammarydysplasia cells of the latter are subject to less hormonal stress (the number of cases of normal lactation after childbirth and ofpathology during pseudopregnancy or artificial inhibition of lactation) than mammary glands of dogs diagnosed with malignant tumors (Table. 1).

Groups of animals with mammary malignant tumors and dysplasia differed on such characteristics as frequency of tumors with full, partial or no capsule, 


\section{Comparative analysis of some characteristics of canine mammary malignant tumors and dysplasia $(M \pm m)$}

\begin{tabular}{|l|l|l|l|l|}
\hline Indicator analyzed & $\mathrm{n}$ & $\begin{array}{l}\text { Malignant } \\
\text { tumor }\end{array}$ & $\mathrm{n}$ & Dysplasia \\
\hline Age at time of treatment (years) & 37 & $10,4 \pm 0,32$ & 13 & $9,15 \pm 0,15 *$ \\
\hline Age at time of occurrence of the disease (years) & 29 & $9,34 \pm 0,44$ & 12 & $7,22 \pm 0,69 *$ \\
\hline Duration of disease (years) & 29 & $0,90 \pm 0,20$ & 12 & $1,70 \pm 0,37 *$ \\
\hline $\begin{array}{l}\text { Period between giving birth and recent factors of } \\
\text { disease (years) }\end{array}$ & 22 & $4,64 \pm 0,58$ & 8 & $5,25 \pm 0,77$ \\
\hline Number of giving birth during life (1 animal) & 31 & $1,61 \pm 0,26$ & 13 & $0,69 \pm 0,17 *$ \\
\hline $\begin{array}{l}\text { Number of cases of lactation malfunction (points } \\
\text { per animal) }\end{array}$ & 31 & $1,06 \pm 0,20$ & 13 & $0,62 \pm 0,24$ \\
\hline Neoplasms size (cm $\left.)^{3}\right)$ & 31 & $555,9 \pm 218,6$ & 13 & $124,9 \pm 33,4 *$ \\
\hline Capsules (points per animal) & 37 & $1,38 \pm 0,11$ & 13 & $1,38 \pm 0,21$ \\
\hline Number of affected mammary gland (1 animal) & 32 & $1,91 \pm 0,21$ & 13 & $2,23 \pm 0,36$ \\
\hline $\begin{array}{l}\text { Number of affected right mammary gland (1 } \\
\text { animal) }\end{array}$ & 32 & $0,94 \pm 0,14$ & 13 & $1,08 \pm 0,28$ \\
\hline $\begin{array}{l}\text { Number of affected left mammary gland (1 } \\
\text { animal) }\end{array}$ & 32 & $0,97 \pm 0,18$ & 13 & $1,15 \pm 0,27$ \\
\hline $\begin{array}{l}\text { Number of affected 1st package mammary gland } \\
(1 \text { animal) }\end{array}$ & 32 & $0,09 \pm 0,05$ & 13 & $0,15 \pm 0,10$ \\
\hline $\begin{array}{l}\text { Number of affected 2nd package mammary } \\
\text { gland (1 animal) }\end{array}$ & 32 & $0,06 \pm 0,04$ & 13 & $0,23 \pm 0,12$ \\
\hline $\begin{array}{l}\text { Number of affected 3rd package mammary gland } \\
(1 \text { animal) }\end{array}$ & 32 & $0,50 \pm 0,11 * *$ & 13 & $0,54 \pm 0,18 * *$ \\
\hline $\begin{array}{l}\text { Number of affected 4th package mammary gland } \\
(1 \text { animal) }\end{array}$ & 32 & $0,69 \pm 0,11 * *$ & 13 & $0,69 \pm 0,17 * *$ \\
\hline $\begin{array}{l}\text { Number of affected 5th package mammary gland } \\
(1 \text { animal) }\end{array}$ & 32 & $0,57 \pm 0,10 * *$ & 13 & $0,62 \pm 0,21 * *$ \\
\hline
\end{tabular}

Notes: The likely difference $(\mathrm{P}<0,05)$ : * - with a group of «malignant tumors»; ** - with a group of «number of affected 1st packagemammary gland»

and the average number of mammary glandaffected (in 1 animal) and their localization (Table 1). The data on the unequal incidence of involvement of different mammary packages entirely coincide with those in the literature (Nguyen, 2018): $65 \%$ of tumors localized in 2 posteriors, $26 \%$ - an average and $8 \%$ in two anterior packages.

13 of 37 cases of malignant mammary tumors in dogs were due to lobular or ductal hyperplasia. The possible differences between the studied indicators in groups of dogs with malignant mam- mary tumors and dogs with malignant tumors that were diagnosed with dysplasia were researched. The analysis found no significant difference between the two groups except that the size of tumors without surrounding tissue hyperplasia was larger than those diagnosed with atypical hyperplasia (749,9 $\pm 329,5$ and $197,8 \pm 88,9$ respectively). Some authors believe that proliferative, dysplastic affection can be considered early stages of carcinogenesis (Zarydze, 2004). However, we should agree with other scientists that the role of these 
factors in the pathogenesis of malignant mammary tumors in dogs is unknown (Martin de las Mulas, 2002).

\section{Discussion}

The first factors of mammarydysplasia in dogs were developed earlier than mammary glandmalignancies the further growth of which, in turn, was much faster. Dogs with dysplasia gave birth twice as less and had slightly fewer cases of lactation disorders than those with diagnosed malignancies. The size of tumors without surrounding tissue hyperplasia was higher than those diagnosed with atypical lobular or ductal hyperplasia.

\section{References}

Abelev, G.I., Al'tshteyn, A.D., Belitskiy, G.A., Vasil'yev, YU.M. (2000). Kantserogenez [Carcinogenesis]. Moskva: Nauch. mir, 418.

Kosmacheva, Ye.P. (2003). Proliferativnyye zabolevaniya molochnoy zhelezy sobak [Proliferative diseases of the mammary gland of dogs]. Veterinarnyy konsul'tant., 9-10, 29-30.

Horal's'kyy, L.P., Khomych, V.T., Konons'kyy, O.I. (2015). Osnovy histolohichnoyi tekhniky i morfofunktsional'ni metody doslidzhen' u normi ta pry patolohiyi [Fundamentals of histological technique and morphofunctional methods of research in norm and at pathology]: Navchal'nyy posibnyk. Zhytomyr: Polissya, 286.

Avramenko, Y.V. (2001). Pukhlyny dribnykh sviys'kykh tvaryn: klinika, diahnostyka, likuvannya [Tumors of small domestic animals: clinic, diagnostics, treatment ] / za red. Chekhuna V.F. ta Mazurkevycha A.Y. Kyyiv: DIA, 164.

Trapezov, Ye.V. (2004). Primeneniye metoda akupuntury dlya preryvaniya lozhnoy beremennosti u sobak [The use of the method of acupuncture to abort false pregnancy in dogs]. Veterinar., 4: 26-31.

Alessandro, Di Cerbo, Beniamino Palmieri, Gionata De Vico, and Tommaso Iannitti. (2014). Onco-epidemiology of domestic animals and targeted therapeutic attempts: perspectives on human oncology. J Cancer Res Clin Oncol., 140 (11): 1807-1814. (doi:10.1007/s00432-014-1664-9)

Blank, EW, Wong, PY, Lakshmanaswamy, R, Guzman, R, Nandi, S. (2008). Both ovarian hormones estrogen and progesterone are necessary for hormonal mammarycarcinogenesis in ovariectomized $\mathrm{ACl}$ rats. Proc. Natl. Acad. Sci. U S A, 1059: 3527-3532. (doi: 10.1073/pnas.0710535105)

Fitzgibbons, P., Henson, D., Hutter, R. (1998). Benign breast changes and the risk of subsequent breast cancer, an update of the 1985 consensus statement. Arch. Pathol. Lab. Med., 122: 1053-1055.

Misdorp, W., Else, R., Hellmen, E., Lipscomb, T. (1999). Histological Classification of mammary tumors of the dog and cat / Eds. Armed Forces Inst. Pathol. in cooperation with Amer. Registry of Pathol. and World Health Organization Collaborating Center for World Reference on Compar. Oncol. Washington, DC., 58.

Junters, P., Znidersic, L., Pogacnik, M. (2000). Epidemiology of tumors in a defined population of dogs. 11th Ljudevit Jurak international symposium on comparative pathology: Book of abstract. Zagreb: Kratis, 10-11. Martin de las Mulas J., Reymundo, C. (2000). Animal models of human breast carcinoma: canine and feline neoplasm. Rev. Oncologia, 2: 274-281.

Nguyen, F, Peña, L, Ibisch, C, Loussouarn, D, Gama, A, Rieder, N, Belousov, A, Campone, M, Abadie J. (2018). Canine invasive mammary carcinomas as models of human breast cancer. Part 1: natural history and prognostic factors. Breast Cancer Res Treat., 167(3): 635-648. (doi: 10.1007/ s10549-017-4548-2) 
Meuten, D. (2002). Tumor in domestic animals / Ed. lowa State Press, 575-584.

Veronesi, MC, Battocchio, M, Rizzi, C, Sironi, G. (2003). Relationship between dysplastic and neoplastic mammary lesions and pseudopregnancy in the bitch. Vet Res Commun., 1: 245-247.
Yaritza Salas, Adelys Márquez, Daniel Diaz, and Laura Romero. (2015). Epidemiological Study of Mammary Tumors in Female Dogs Diagnosed during the Period 20022012: A Growing Animal Health Problem., 10(5): 134-142. (doi:10.1371/journal. pone.0127381)

\section{Михайленко Н. І., Кмітевич Є. О. (2019). АНАМНЕСТИЧНІ, КЛІНІЧНІ ТА ПАТОМОРФОЛОГІЧНІ ХАРАКТЕРИСТИКИ ЗЛОЯКІСНИХ ПУХЛИН ТА ДИСПЛАЗІї МОЛОЧНОї ЗАЛОЗИ СОБАК. Ukrainian Journal of Veterinary Sciences, 9(3): 50-55, https://doi.org/10.31548/ujvs2019.03.007.}

Анотація. У роботі були співставленні параметри дисплазії молочної залози та злоякісних новоутворень цієї ж локалізації. Аналізували середній вік собак під час оперативного втручання, на момент реєстрації перших симптомів онкологічної патології, кількість пологів, їх періодичність, наявність симптомів псевдовагітності та лактації, кількість новоутворень та їх локалізацію, а також зовнішній вигляд пухлин. Для визначення якісних характеристик був застосований метод ранжирування, за якого наявність капсули у пухлинах та патології лактації оцінювали у балах.

Власники із собаками, у яких діагностували дисплазію молочних залоз, звертались до лікаря у більш молодому віці, ніж із тваринами, у яких був поставлений діагноз на злоякісні новоутворення. Можливо це пов'язано із більш раннім початком захворювання на дисплазію, ніж на злоякісні пухлини. Водночас період між виявленням пухлини та оперативним втручанням у випадках злоякісних пухлин менший, що може вказувати про більш швидке збільшення розмірів злоякісних новоутворень, ніж дисплазій. за аналізу значення кількості родів у виникненні різних пухлин молочних залоз з'ясовано, що собаки із дисплазією народжували у двічі менше. Час між останніми пологами та появою перших ознак захворювання для обох груп тварин виявився однаковим. Не встановлено вірогідної різниці у кількості епізодів порушення лактації у собак зі злоякісними новоутвореннями та у собак із дисплазією молочних залоз. Групи тварин як із злоякісними новоутвореннями, так і з дисплазією не відрізнялися між собою за такими характеристиками як частота реєстрачії новоутворень із повною, частковою капсулою або ії відсутністю, а такожза середньою кількістю уражених молочних залоз та їх локалізацією.

Ключові слова: ветеринарна онкологія, пухлини молочної залози, злоякісні пухлини, дисплазія молочної залози, собаки 